\title{
Peningkatan Keterampilan Mengajar Mahasiswa pada Anak Usia Dini melalui Metode Drill
}

\author{
Muhammad Nasirun $^{1 凶}$, Yulidesni $^{2}$, Melia Eka Daryati ${ }^{3}$ \\ Pendidikan Guru Pendidikan Anak Usia Dini, Universitas Bengkulu \\ DOI: $\underline{10.31004 / \text { obsesi.v5i1.506 }}$
}

\begin{abstract}
Abstrak
Keterampilan mengajar yang belum optimal pada mahasiswa semester ganjil terkhusus pada Semester V menyebabkan menurunnya kualitas pelaksanaan praktek mengajar pada Mahasiswa Program Studi S1 Pendidikan Guru Pendidikan Anak Usia Dini (PGPAUD) Tahun Ajaran 2019/2020 FKIP Universitas Bengkulu. Tujuan penelitian ini untuk meningkatkan keterampilan mengajar pada mahasiswa Semester V menggunakan metode drill. Jenis penelitian menggunakan Penelitian Tindakan Kelas (PTK). Subjek penelitian sebanyak 75 orang. Teknik pengumpulan data menggunakan observasi. Hasil penelitian menunjukkan melalui penggunaan metode drill tidak meningkatkan keterampilan dasar mengajar dengan nilai rata-rata 73 siklus 1 dan nilai rata-rata 75 pada siklus 2. Bagi penelitian berikutnya disarankan agar penerapan praktek latihan mengajar hendaknya menerapkan semua keterampilan dasar mengajar dengan beberapa kali latihan dengan estimasi waktu yang cukup, serta penilaian dilakukan oleh ahli pembelajaran.
\end{abstract}

Kata Kunci: keterampilan mengajar; mahasiswa pgpaud, metode drill.

\begin{abstract}
Teaching skills are not optimal in odd semester students, especially in Semester V caused a decrease in the quality of teaching practice implementation of Early Childhood Education Teacher Study Program Students in 2019/2020 Departement of Education Bengkulu University. The purpose of this study was to improve teaching skills in fifth-semester students using the drill method. This type of research uses Classroom Action Research (CAR). The subjects of the study as many as 75 people. Data collection techniques using observation. The results showed through the use of the drill method did not improve the basic teaching skill of with an average value of 73 cycles 1 and an average value of 75 in cycles 2. For the next research, it is suggested that the implementation of teaching practice should apply all basic teaching skills with several exercises with sufficient estimated time, as well as an assessment conducted by learning experts.
\end{abstract}

Keywords: teaching skills; student of early childhood teacher education; drill method.

Copyright (c) 2020 Muhammad Nasirun, Yulidesni, Melia Eka Daryati

$\triangle$ Corresponding author:

Email Address : melia_eka@unib.ac.id (Bengkulu, Indonesia)

Received 23 Maret 2020, Accepted 6 June 2020, Published 8 July 2020 


\section{PENDAHULUAN.}

Penyelenggaraan kegiatan belajar mengajar pada lembaga pendidikan anak usia dini dilakukan melalui suatu proses yang melibatkan peran pendidik sebagai fasilitator yang berprofesi untuk menstimulasi kemampuan dari dalam diri setiap peserta didik. Keberhasilan suatu proses belajar mengajar untuk anak usia dini sangat ditentukan bagaimana tingkat kualitas pendidik dalam mentrasfer suatu ilmu. Ilmu pengetahuan yang dimiliki pada peserta didik pada dasarnya akan berkembang bila anak diberikan suatu fasilitas dan didampingi dalam setiap kegiatan belajar mengajar. Minat akan profesi pendidik meningkatkan motivasi dan keterampilan dalam proses belajar mengajar (Hidayat, 2016).

Pendidik memegang peran sebagai sutradara sekaligus aktor dan merupakan faktor yang sangat dominan dalam menentukan keberhasilan proses belajar mengajar di kelas (Saragih, 2008). Pendampingan yang dilakukan pendidik saat proses belajar mengajar haruslah bermakna dan menumbuhkan inisiatif berupa bermain, menyimak dan bercerita dari dalam diri anak untuk melakukan beberapa aktivitas yang dilakukan saat proses belajar mengajar berlangsung, tanpa disadari aktivitas belajar didasari minat terhadap ketertarikan, menurut penelitian terdapat hubungan yang positif akan minat dengan keterampilan mengejajar (Wahyuni, 2015). Kegiatan belajar mengajar harus didasari suatu keterampilan dan pemahaman dalam menjalankan peran sebagai pendidik anak usia dini. Menurut penelitian Taja, Inten, and Hakim mengatakan bahwa aktivitas bermain, menyimak dan bercerita pada anak usia dini meningkatkan pemahaman rata-rata pendidik setalah penggunaan teknik MATA (Taja et al., 2019).

Persyaratan bagi pendidik untuk memiliki keterampilan mengajar yang baik, pendidik harus terus meningkatkan keterampilan mengajar mereka dan mengembangkan cara mengajar yang lebih efektif agar tidak tumpang tindih dengan kemudahan yang disajikan oleh media teknologi. Para pendidik saat ini dituntut untuk memiliki keterampilan mengajar yang terkini dan berdasarkan pada teknologi yang sudah ada (Mansur, 2017). Keterampilan dapat diartikan sebagai suatu kemampuan dalam mempergunakan akal, ide, serta kreatifitas dalam mengerjakan, membuat ataupun mengubah sesuatu menjadi yang lebih bermakna sehingga dapat menghasilkan sebuah nilai tambah dari hasil yang dikerjakan tersebut. Secara khusus keterampilan dalam mengajar adalah suatu cara yang dipakai untuk mengemukakan pendapat, mempertahankan, dan mengungkapkan pengetahuan serta merupakan cara untuk menyelesaikan masalah (Halimah, 2017).

Keterampilan guru dalam mengajar berperan dalam peningkatan mutu dan aktivitas anak didik dalam kelas, perkembangan dan kemajuan anak didik dipengaruhi oleh bagaiamana seorang guru mampu untuk memberikan rasa yang kuat untuk mengembangkan potensi melalui aktivitas belaja anak didik, hal ini sesuia penelitian yang menyatakan Keterampilan seorang guru mempengaruhi aktivitas belajar siswa (Nuridin et al., 2019).

Keterampilan yang dimiliki pendidik anak usia dini sangatlah banyak, tidak semua yang mengajar bila berhadapan langsung dengan anak langsung bisa mengajar, karena mengajar setidaknya memerlukan delapan keterampilan yang harus dikuasai oleh pendidik. Delapan keterampilan mengajar yang harus dilakukan pendidik dalam pelaksanaan pembelajaran yaitu: keterampilan membuka dan menutup pelajaran, keterampilan menjelaskan, keterampilan mengelola kelas, keterampilan variasi, keterampilan reinforcement, keterampilan bertanya dasar dan lanjut (Djamarah, syaiful Bahri, 2006).

Delapan keterampilan ini memiliki konsep dan skill yang berbeda-beda, satu keterampilan memerlukan latihan dan praktek dalam menerapkannya. Untuk itu sebelum mahasiswa ke lapangan dan praktek langsung kepada anak usia dini, sebaiknya para mahasiswa melakukan praktek dan latihan mengenai delapan keterampilan mengajar yang harus dikuasai oleh mahasiswa baik konsep maupun keterampilan spesifik setiap komponen. Keterampilan dalam proses mengajar menumbuhkan kreativitas anak karena 
anak lebih mandiri, percaya diri, berani berpendapat, dan rasa ingin tahu yeng tinggi sebagai ciri kreatif (Marwiyati \& Istiningsih, 2021). Keterampilan mahasiswa akan memberikan penguatan yang baik sebagai calon guru dengan respon kegiatan anak didik berupa kata-kata atau kegiatan yang menciptakan kehangatan serta kebermakanaan berlangsung proses belajar dalam proses belajar menganjar (Nurlaili, 2018).

Menurut penelitian menyatakan Hasil dari penelitian ini adalah terdapat 8 Keterampilan Dasar Mengajar yang dianggap sangat berperan dalam keberhasilan kegiatan belajar mengajar, yaitu keterampilan bertanya, keterampilan memberikan penguatan, keterampilan mengadakan variasi, keterampilan menjelaskan, keterampilan membuka dan menutup pelajaran, keterampilan membimbing diskusi kelompok kecil, keterampilan mengelola kelas, keterampilan mengajar kelompok kecil dan perseorangan (Wahyulestari, 2018). Penelitian lain menyatakan dalam proses belajar suatu mata pelajaran anak dituntut untuk bersedia melaksanakan latihan-latihan untuk menambahkan rasa percaya diri, kemauan yang keras dalam menerapkan strategi belajar yang tepat, perencanaan dan pengaturan diri yang baik agar dapat tercapainya hasil belajar yang tinggi (Mansur, 2017).

Kegiatan menerapkan kedelapan keterampilan mengajar dilakukan pada mata kuliah strategi pembelajaran yang dilakukan pada mahasiswa Semester V Program Studi S1 Pendidikan Guru PAUD Tahun Ajaran 2019/2020 FKIP Universitas Bengkulu. Proses perkuliahan diawali dengan pemaparan materi mengenai delapan keterampilan mengajar. Dari kegiatan tersebut ternyata diperoleh mahasiswa yang masih sibuk sendiri dengan aktivitas pribadi tanpa menyimak kegiatan yang dilakukan saat penyampaian materi, saat proses tanya jawab masih terdapat beberapa mahasiswa yang belum memahami konsep keterampilan mengajar yang sudah dijelaskan sebelumnya, terdapat juga respon mahasiswa yang masih malu dalam mencontohkan beberapa keterampilan saat proses perkuliahan berlangsung. Hal inilah yang menjadi bahan evaluasi bagaimana caranya agar delapan keterampilan ini bisa dikuasai oleh mahasiswa dan mahasiswa bisa menerapkan keterampilan dalam praktek mengajar saat proses perkuliahan berlangsung, karena menurut penelitian Salma \& Fatmawati untuk meningkatkan kemampuan anak perlu melakukan keterampilan melalui proses latihan yang dilakukan secara berulang-ulang dan bersungguhsungguh (Salma \& Fatmawati, 2019).

Salah satu penyebab rendahnya kemampuan keterampilan mengajar mahasiswa dikarenakan metode pengajaran yang masih bersifat ceramah dan tanya jawab, padahal untuk menerapkan kedelapan keterampilan mengajar perlu dilakukan suatu metode yang berpusat pada meningkatan keterampilan, memerlukan metode yang menerapkan latihan dan penggunaan metode yang bisa dilakukan secara berulang-ulang dalam menerapkan kedelapan keterampilan mengajar.

Penerapan metode yang diyakini sebagai alternative dalam meningkatkan keterampilan mengajar dengan menggunakan metode drill. Metode drill mampu menerapkan kedelapan keterampilan mengajar karena dalam penerapannya menggunakan proses praktek dan latihan yang berulang sehingga diyakini dapat memperkuat suatu konsep dan penyempurnaan keterampilan melalui praktek yang dilakukan secara bersungguh-sungguh, untuk membuat mahasiswa menguasai delapan keterampilan dasar mengajar harus dilakukan dalam proses latihan mengajar yang terecana, bertahap, berlapis sistematis dan berkelanjutan (Ismail, 2015)

Menurut penelitian Purwati dalam Salma \& Fatmawati menyatakan bahwa metode drill merupakan suatu kegiatan untuk melakukan hal yang sama secara berulang-ulang dan sungguh-sungguh yang bertujuan untuk memperkuat dan menyempurnakan suatu keterampilan supaya menjadi permanen (Salma \& Fatmawati, 2019), sehingga mahasiswa mampu memahami keterampilan dalam mengajar karena sudah dilakukan pembiasaan dan penguatan terhadap delapan keterampilan dalam mengajar. Mahasiswa sebagai calon guru dengan adanya metode drill akan membantu peningkatan mutu dalam kelas. Peneliltian lainya menyatakan penggunaan metode driil dalam kelas akan meningkatkan kemampun 
dalam menulis siswa (Nikmarijal \& Ifdil, 2014), dari penelitin lain mengemukakan bahwa metode drill diberikan kepada anak didik dapat meningkatkan kemampuan menulis puisi (Rahmadani et al., 2015).

Berdasarkan penelitian yang terdahulu yang dilakukan oleh Wahyu, Syambasril (2017) penerapan metode drill melalui cara mengajar dimana anak melakukan kegiatankegiatan latihan agar anak memiliki ketangkasan atau keterampilan lebih tinggi dari apa yang dipelajari. Dipertegas juga oleh Ahmadi dalam (Oliver, 2019) menyatakan bahwa metode drill atau disebut latihan, dimaksudkan untuk memperoleh ketangkasan atau keterampilan latihan terhadap apa yang dipelajari, karena hanya dengan melakukannya secara praktis suatu pengetahuan dapat disempurnakan dan disiap siagakan. Menurut penelitian penerapan metode drill dapat meningkatkan hasil belajar kognitif (Astuningtias \& Appulembang, 2017), Penelitian ini senada menyatakan meningkatkan kemampuan tunarunggu dalam keterampilan (Salma \& Fatmawati, 2019).

Menurut penelitian Zakiya \& Nurhafizah menyatakan bahwa untuk mengembangan keprofesionalan berkelanjutan seorang pendidik pendidikan anak usia dini memerlukan proses pemahaman pendidikan dan latihan yang berhubungan dengan peningktan professional (Maiza \& Nurhafizah, 2019). Hal ini selaras dengan tujuan dalam mengembangkan keterampilan mengajar sebagai proses dan tahapan untuk menjadi pendidik pendidik anak usia dini yang professional. Menurut Roestiyah pelaksanaan pengembangan keterampilan mengajar dengan metode drill diantaranya adalah: 1) agar anak lebih terampil, cepat dan tepat, karena anak diajak melakukan kegiatan secara langsung dan berulang-ulang, 2) Mendukung keberhasilan kegiatan jika kegiatan dilakukan secara berlatih dan berulang-ulang, 3) Memberikan keterampilan tertentu (Roestiyah, 2008).

Penerapan metode drill memiliki beberapa kelebihan diantaranya adalah: 1) untuk memperoleh kecakapan motorik, seperti: menulis, melafalkan huruf, kata dan kalimat, 2) untuk memperoleh kecakapan pengetahuan seperti perkalian, pengurangan, pembagian dan sebagainya, 3) pembentukan kebiasaan yang dilakukan dan memperoleh ketepatan dan kecepatan pelaksanaan, 4) pembentukan kebiasaan-kebiasaan membuat gerakan-gerakan yang kompleks, rumit, menjadi lebih otomatis (Djamarah, syaiful Bahri, 2006).

Disimpulkan bahwa penerapan metode drill adalah suatu metode pembelajaran yang membantu anak dalam memahami setiap langkah pengajaran yang sesuai dengan kebiasaan yang diajarkan secara berulang-ulang. Berdasarkan hasil penelitian relevan dan fakta mengenai metode drill yang dapat dijadikan salah satu alternatif untuk meningkatkan keterampilan mengajar pada mahasiswa Semester V Program Studi S1 Pendidikan Guru PAUD Tahun Ajaran 2019/2020 FKIP Universitas Bengkulu.

\section{METODOLOGI}

Penelitian ini dilakukan pada mahasiswa Semester V Prodi S1 Pendidikan Guru PAUD Fakultas Kependidikan dan Ilmu Pendidikan Universitas Bengkulu tahun ajaran 2019/2020 sebanyak 75 orang. Tujuan penelitian dilakukan untuk mengetahui upaya peningkatan keterampilan mengajar melalui metode drill. Metode penelitian yang digunakan adalah penelitian tindakan (action research), model kemmis dan Mc Taggart. Perencanaan penelitian tindakan ini menggunakan dua siklus, siklus I sebanyak lima kali pertemuan dan siklus II sebanyak empat kali pertemuan. Perencanaan sebagai dasar untuk memecahkan masalah. Apabila siklus pertama belum tercapai maka dilanjutkan pada siklus kedua dan seterusnya sampai tercapai tujuan penelitian. Penelitian ini dilakukan bersama kolaborator yang akan memberikan tindakan dan peneliti sebagai obsever. Teknik analis data yang dilakukan dalam penelitian ini adalah dua yaitu analisis data kuantitatif dan analisis data kualitatif menggunakan observasi. 


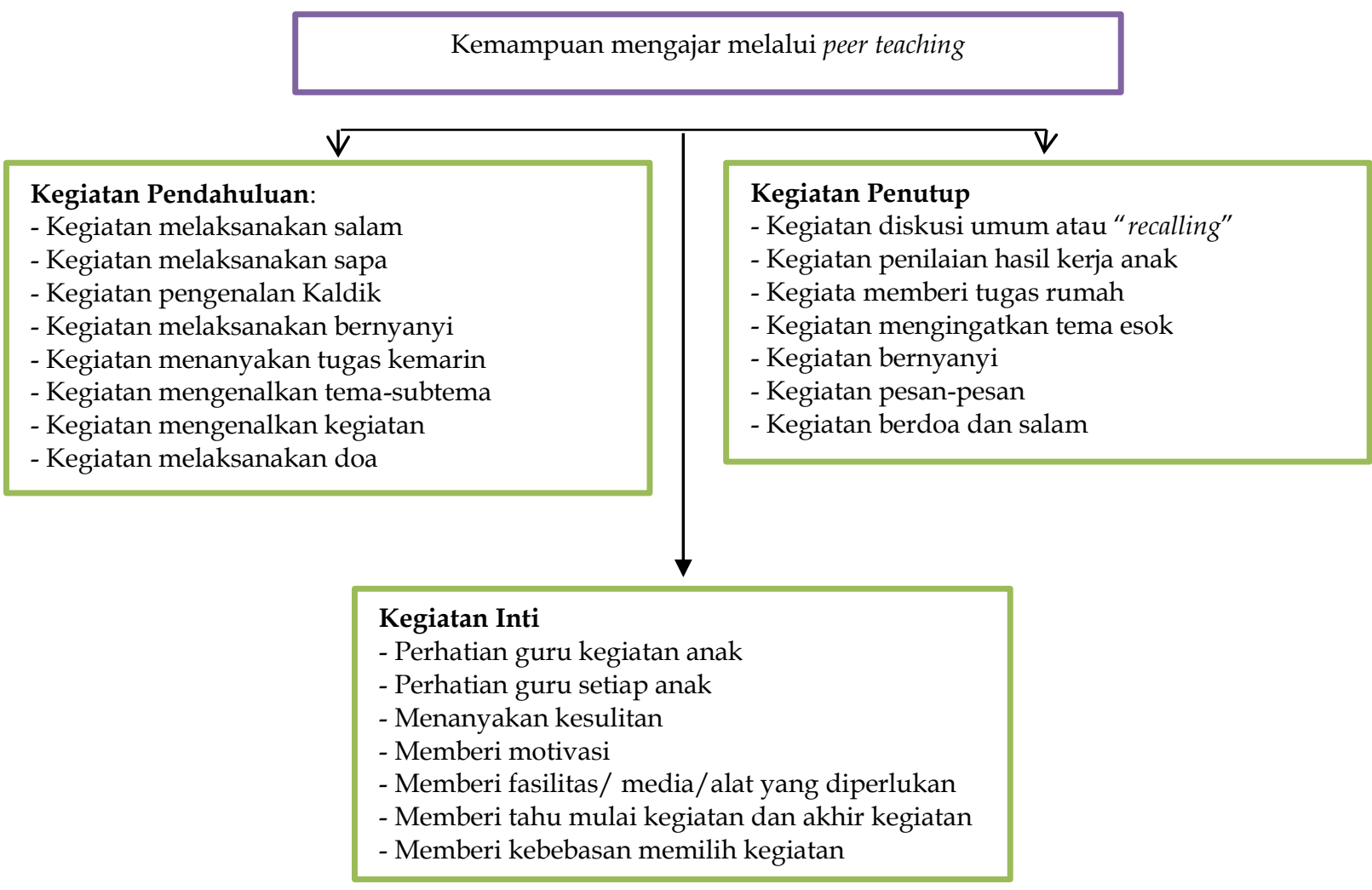

Bagan 1. Kemampuan Mengajar Peer Teaching

\section{HASIL DAN PEMBAHASAN}

Hasil penelitian yang dilakukan pada mahasiswa Semester V Prodi S1 Pendidikan Guru PAUD Fakultas Kependidikan dan Ilmu Pendidikan Universitas Bengkulu tahun ajaran 2019/2020, menunjukkan bahwa melalui metode drill dapat meningkatkan keterampilan mengajar pada mahasiswa dengan keseluruhan skor terakhir sebesar 75\%. Hasil Analisis data pada penelitian ini bertujuan untuk melihat proses penerapan metode drill dalam meningkatkan keterampilan mengajar. Hasil penilaian autentik peningkatan keterampilan mengajar melalui metode drill pada siklus I dan siklus II dapat dilihat pada tabel berikut ini:

Tabel 1. Rekap Penilaian Sejawat Keterampilan Mengajar Kelas A dan Kelas B Siklus I

\begin{tabular}{lccc}
\hline \multicolumn{1}{c}{ Jenis } & Kelas & Kelas & $\overline{\boldsymbol{x}} /$ \\
\multicolumn{1}{c}{ Ketrampilan } & $\mathrm{A}$ & $\mathrm{B}$ & Kriteria \\
\hline Keterampilan Membuka & $\mathbf{8 0}$ & $\mathbf{7 4}$ & $\mathbf{7 7}$ \\
Keterampilan Menutup & 77 & $\mathbf{7 2}$ & $\mathbf{7 4 , 5}$ \\
Keterampilan Menjelaskan & $\mathbf{7 4}$ & $\mathbf{6 0}$ & $\mathbf{6 7}$ \\
Keterampilan Mengelola Kelas & $\mathbf{7 6}$ & $\mathbf{7 0}$ & $\mathbf{7 3}$ \\
Keterampilan Variasi & $\mathbf{8 6}$ & $\mathbf{7 4}$ & $\mathbf{8 0}$ \\
Keterampilan Reinforcement & $\mathbf{7 4}$ & $\mathbf{7 7}$ & $\mathbf{7 5 , 5}$ \\
Keterampilan Bertanya Dasar & $\mathbf{7 9}$ & $\mathbf{6 9}$ & $\mathbf{7 4}$ \\
Keterampilan Bertanya Lanjutan & $\mathbf{7 8}$ & $\mathbf{7 7}$ & $\mathbf{7 7 , 5}$ \\
\hline Rata-rata & $\mathbf{7 8}$ & $\mathbf{7 1 , 6 2 5}$ & $\mathbf{7 4 , 8 1 2 5}$ \\
\hline
\end{tabular}

Berdasarkan tabel diatas keterangan kategori keberhasilan anak dapat dilihat sebagai berikut : 
Tebel 2 Kategori Keberhasilan

\begin{tabular}{cc}
\hline Skor & Kategori \\
\hline $80-96$ & SB (Sangat Baik) \\
$70-79$ & B (Baik) \\
$60-69$ & C (Cukup) \\
$50-59$ & K (Kurang) \\
\hline
\end{tabular}

Berdasarkan tabel di atas dapat disimpulkan bahwa pelaksanaan latihan keterampilan mengajar dengan jenis keterampilan membuka dan menutup pelajaran, keterampilan menjelaskan, keterampilan bertanya, keterampilan memberi penguatan, keterampilan mengelola kelas dan keterampilan variasi yang dilakukan pada siklus pertama secara umum keterampilan mengajar pada kelas A dan kelas B berada pada kategori baik (B) dengan rata-rata 74,8125\%.

Hasil penilaian selanjutnya dilakukan pada siklus kedua yang dapat dilihat pada Tabel 3 berikut ini:

Tabel 3 Rekap Penilaian Sejawat Keterampilan Mengajar Kelas A dan Kelas B Siklus II

\begin{tabular}{lccc}
\hline \multicolumn{1}{c}{ Jenis } & Kelas & Kelas & $\overline{\boldsymbol{x}} /$ \\
Ketrampilan & $\mathrm{A}$ & $\mathrm{B}$ & Kriteria \\
\hline Keterampilan Membuka & $\mathbf{7 2}$ & $\mathbf{8 8}$ & $\mathbf{8 0}$ \\
Keterampilan Menutup & $\mathbf{7 8}$ & $\mathbf{7 5}$ & $\mathbf{7 6 , 5}$ \\
Keterampilan Menjelaskan & $\mathbf{7 8}$ & $\mathbf{6 8}$ & $\mathbf{7 3}$ \\
Keterampilan Mengelola Kelas & $\mathbf{8 3}$ & $\mathbf{8 3}$ & $\mathbf{8 3}$ \\
Keterampilan Variasi & $\mathbf{8 0}$ & $\mathbf{8 2}$ & $\mathbf{8 1}$ \\
Keterampilan Reinforcement & $\mathbf{7 0}$ & $\mathbf{7 2}$ & $\mathbf{7 1}$ \\
Keterampilan Bertanya Dasar & $\mathbf{7 6}$ & $\mathbf{7 7}$ & $\mathbf{7 6 , 5}$ \\
Keterampilan Bertanya Lanjutan & $\mathbf{7 4}$ & $\mathbf{7 5}$ & $\mathbf{7 4 , 5}$ \\
Rata-rata & $\mathbf{7 6 , 3 7 5}$ & $\mathbf{7 7 , 5}$ & $\mathbf{7 6 , 9 3 7 5}$ \\
\hline
\end{tabular}

Berdasarkan tabel di atas dapat disimpulkan bahwa pelaksanaan latihan keterampilan mengajar dengan jenis keterampilan membuka dan menutup pelajaran, keterampilan menjelaskan, keterampilan bertanya, keterampilan memberi penguatan, keterampilan mengelola kelas dan keterampilan variasi yang dilakukan pada siklus kedua secara umum latihan praktik keterampilan mengajar pada kelas A dan kelas B berada pada kategori Baik (B) dengan nilai rata-rata $76,9375 \%$.

Hasil penilaian secara kumulatif mengenai proses peningkatan keterampilan mengajar melalui metode drill yang telah dilakukan pada siklus pertama dan siklus kedua disajikan pada tabel 4 berikut ini:

Tabel 4 Rekap Penilaian Sejawat Keterampilan Mengajar Kelas A Dan Kelas B (Siklus I Dan Siklus II)

\begin{tabular}{|c|c|c|c|}
\hline $\begin{array}{c}\text { Jenis } \\
\text { Ketrampilan }\end{array}$ & $\begin{array}{c}\text { Kelas } \\
\text { A }\end{array}$ & $\begin{array}{c}\text { Kelas } \\
\text { B }\end{array}$ & Keterangan \\
\hline Keterampilan Membuka & 77 & 80 & Meningkat \\
\hline Keterampilan Menutup & 74,5 & 76,5 & Meningkat \\
\hline Keterampilan Menjelaskan & 67 & 73 & Meningkat \\
\hline Keterampilan Mengelola Kelas & 73 & 83 & Meningkat \\
\hline Keterampilan Variasi & 80 & 81 & Meningkat \\
\hline Keterampilan Reinforcement & 75,5 & 71 & Menurun \\
\hline Keterampilan Bertanya Dasar & 74 & 76,5 & Meningkat \\
\hline Keterampilan Bertanya Lanjutan & 77,5 & 74,5 & Menurun \\
\hline Rata-rata & 74,8125 & 76,9375 & Meningkat \\
\hline
\end{tabular}


Apabila dibandingkan kemampuan mengajar mahasiswa pada siklus pertama dan siklus kedua tindakan yang diberikan dengan menggunakan metode drill telah mengalami peningkatan. Walaupun peningkatan yang terjadi tidak terlalu tinggi namun sudah melebihi indikator keberhasilan yang ditetapkan sebelum penelitian berlansung. Jadi penelitian ini dapat dikatakan berhasil karena mahasiswa sudah melebih indikator keberhasilan sebesar $75 \%$. Maka dari itu penggunaan metode drill mampu meningkatkan keterampilan mengajar pada mahasiswa Semester V Prodi S1 Pendidikan Guru PAUD Fakultas Kependidikan dan Ilmu Pendidikan Universitas Bengkulu tahun ajaran 2019/2020.

\section{Pembahasan}

\section{Proses Penggunaan Metode Drill yang Mampu Meningkatkan Keterampilan Mengajar}

Pemilihan metode drill pada penelitian ini didasari adanya landasan kemampuan untuk menerapkan kedelapan keterampilan mengajar karena dalam penerapannya menggunakan proses praktek dan latihan yang berulang sehingga diyakini dapat memperkuat suatu konsep dan penyempurnaan keterampilan melalui praktek yang dilakukan secara bersungguh-sungguh. Metode drill Peningkatan keterampilan mengajar memerlukan kegiatan yang melibatkan keterpaduan antara pemahaman, praktek dan latihan yang dilakukan secara berurutan mengenai kedelapan keterampilan mengajar yang perlu dimiliki oleh mahasiswa. Metode drill bagian dari perangkat dalam proses belajar dalam meningkatkan keterampilan mengajar (Safitri \& Sontani, 2016).

Penerapan metode drill memiliki keterhubungan dalam meningkatkan keterampilan mengajar karena adanya proses pemahaman suatu materi, praktek secara langsung, dan pengembangan keterampilan yang dilakukan secara berulang-ulang. Sehingga pelaksanaan metode drill sangat diyakini dapat meningkatkan keterampilan mengajar pada mahasiswa.

Proses yang dilakukan selama penelitian dengan menerapkan metode drill diantaranya adalah 1) Pendidik menyampaikan tujuan pembelajaran mengenai keterampilan mengajar yang harus dikuasai oleh mahasiswa, 2) Pendidik menjelaskan materi pelajaran bahwasannya dalam mengembangkan keterampilan mengajar terdapat delapan keterampilan yang perlu dikuasai oleh mahasiswa, 3) Pendidik memberikan tugas praktek kepada mahasiswa yang bisa dilatih di rumah maupun bisa dilakukan secara bersama-sama di kampus, 4) Pendidik menciptakan suasana menyenangkan saat pembelajaran keterampilan mengajar, 5) Pendidik menarik perhatian mahasiswa dalam pembelajaran dengan menampilkan video pembelajaran, motivasi dalam mengembangkan keterampilan, dan penguatan beberapa keterampilan yang perlu dikuasai oleh mahasiswa, 6) Pendidik melibatkan mahasiswa secara aktif dalam mempraktekkan kedelapan keterampilan mengajar secara berurutan dan bergantian, 7) Pendidik memberikan kesempatan kepada mahasiswa untuk terus berlatih dalam mengembangkan kedelapan keterampilan mengajar dengan cara melibatkan peran aktif para mahasiwa yang lainnya untuk memberikan umpan balik dan penguatan setiap keterampilan yang dipraktekkan, 8) Pendidik memberikan beberapa penguatan keterampilan yang bisa diterapkan dan dilakukan secara berulangulang.

Penerapan metode drill dalam mengembangkan keterampilan mengajar pada mahasswa berpengaruh secara positif, hal ini didukung dengan antusias mahasiswa dalam mempraktekkan kedelapan keterampilan mengajar baik yang dilakukan di rumah maupun di kampus. Adapun delapan keterampilan yang dilakukan peningkatan mengajar diantaranya adalah: 1) Keterampilan membuka pelajaran, 2) Keterampilan menutup pelajaran, 3) Keterampilan menjelaskan, 4) Keterampilan mengelola kelas, 5) Keterampilan variasi, 6) Keterampilan reinforcement, 7) Keterampilan bertanya dasar, dan 8) Keterampilan bertanya lanjut. 
Melalui penerapan metode drill memiliki keterhubungan bahwasannya bila ingin mengembangkan keterampilan maka memerlukan suatu kebiasaan yang langsung melibatkan anak dalam memahami setiap langkah pengajaran yang sesuai dengan kebiasaan yang diajarkan secara berulang-ulang, direncanakan, dan dilakukan secara serius.

Penelitian ini sejalan dengan penelitian yang dilakukan Astuningtias \& Appulembang bila dilakukannya penerapan metode drill saat pelaksanaan proses belajar mengajar merupakan sesuatu yang baik untuk menanamkan kebiasaan-kebiasaan tertentu, serta sebagai sarana untuk memperoleh suatu ketangkasan, ketepatan, kesempatan dan keterampilan (Astuningtias \& Appulembang, 2017).

\section{Hasil Peningkatan Keterampilan Mengajar Menggunakan Metode Drill}

Penelitian tindakan ini fokus pada peningkatan keterampilan mengajar mahasiswa yang terdiri dari beberapa keterampilan diantaranya adalah: 1) Keterampilan membuka pelajaran, 2) Keterampilan menutup pelajaran, 3) Keterampilan menjelaskan, 4) Keterampilan mengelola kelas, 5) Keterampilan variasi, 6) Keterampilan reinforcement, 7) Keterampilan bertanya dasar, dan 8) Keterampilan bertanya lanjut. Hasil penelitian tindakan ini mampu meningkatkan beberapa keterampilan mengajar diantaranya adalah :

Keterampilan membuka pelajaran merupakan kegiatan yang dilakukan pendidik untuk menciptakan suasana siap mental dan menimbulkan perhatian anak agar terpusat pada pelajaran. Keterampilan membuka pelajaran mengalami peningkatan hal ini dapat dilihat ketika proses latihan mengajar mahasiswa sudah menerapkan beberapa keterampilan saat tahapan pembuka pelajaran, terlihat mahasiswa memiliki motivasi dan menciptakan suasana yang menumbuhkan perhatian anak untuk melakukan proses belajar mengajar. Keterampilan mengajar dan motivasi belajar merupakan faktor yang kuat mempengaruhi hasil belajar siswa. Sebagaimana hasil penelitian menunjukkan bahwa keterampilan mengajar pendidik dan motivasi belajar siswa baik secara parsial maupun simultan berpengaruh terhadap hasil belajar, hal ini sesuai dengan penelitian yang menyatakan secara parsial terdapat korelasi kuat antara keterampilan mengajar pendidik dan hasil belajar begitupun motivasi belajar terhadap hasil belajar yang berkorelasi kuat (Safitri \& Sontani, 2016). Hal ini semakin didukung dengan hasil penelitian adanya peningkatan dari nilai 77 pada siklus I naik menjadi 80 pada siklus II.

Keterampilan menutup pelajaran merupakan kegiatan yang dilakukan pendidik untuk mengakhiri kegiatan inti pembelajaran dengan memberikan gambaran menyeluruh tentang apa yang dipelajari, mengetahui tingkat pencapaian anak dan tingkat keberhasilan pendidik dalam proses pembelajaran. Keterampilan menutup pelajaran mengalami peningkatan hal ini dapat dilihat ketika proses latihan mengajar mahasiswa sudah menerapkan beberapa keterampilan saat tahapan penutup pelajaran, terlihat mahasiswa mampu mendorong anak menyelesaikan semua proses pembelajaran yang telah dilakukan dan menerapkan beberapa penguatan terhadap hasil karya anak yang sudah bagus dan yang perlu ditingkatkan. Hal ini semakin didukung dengan hasil penelitian adanya peningkatan dari nilai 74,5 pada siklus I naik menjadi 76,5 pada siklus II.

Keterampilan menjelaskan merupakan aktivitas yang paling sering dilakukan pendidik dalam menyampaikan informasi kepada anak, kegiatan menjelaskan berarti mengorganisasikan materi pembelajaran dalam tata urutan yang terencana secara sitematis sehingga dengan mudah dapat dipahami oleh anak. Keterampilan menjelaskan mengalami peningkatan hal ini dapat dilihat selama proses latihan mengajar, mahasiswa sudah menerapkan beberapa keterampilan saat tahapan pembuka, inti, dan penutup, terlihat mahasiswa mampu membuat anak fokus terhadap materi yang disampaikan. Hal ini semakin didukung dengan hasil penelitian adanya peningkatan dari nilai 67 pada siklus I naik menjadi 73 pada siklus II. 
Keterampilan mengelola kelas menurut Mukminan merupakan kemampuan pendidik untuk menciptakan dan memelihara kondisi belajar yang optimal (Mukminan, 2013). Kondisi optimal dapat dicapai jika pengajar mampu mengatur anak, sarana prasarana, serta mengendalikan suasana yang menyenangkan untuk mencapai kompetensi yang diharapkan. Keterampilan mengelola kelas mengalami peningkatan hal ini dapat dilihat adanya perencanaan penempatan media pembelajaran dan alat permainan edukatif yang akan digunakan oleh anak. Hal ini semakin didukung dengan hasil penelitian adanya peningkatan dari nilai 73 pada siklus I naik menjadi 83 pada siklus II.

Keterampilan variasi menurut Mukminan merupakan perubahan kegiatan pengajar dalam konteks interaksi pembelajaran yang meliputi gaya mengajar, penggunaan media pembelajaran, pola interaksi dengan anak, dan stimulasi (Mukminan, 2013). Keterampilan variasi mengalami peningkatan hal ini dapat dilihat dari adanya interaksi yang hangat antara anak dengan pendidik, menggunakan gaya mengajar yang bervariasi, dan menggunakan media pembelajaran. Hal ini semakin didukung dengan hasil penelitian adanya peningkatan dari nilai 80 pada siklus I naik menjadi 81 pada siklus II.

Keterampilan reinforcement merupakan penyapaian penguatan yang dapat memberikan efek terhadap motivasi belajar dalam jangka panjang (Asrori \& Rasyid, 2009). Menurut Aisyah tujuan memberikan penguatan dalam pembelajaran antara lain : 1) Meningkatkan perhatian anak, 2) Membangkitkan dan memelihara motivasi anak, 3) Memudahkan anak belajar; 4) Mengontrol dan memodifikasi tingkah laku yang kurang positif serta mendorong munculnya tingkah laku yang positif dan produktif (Aisyah, 2007). Keterampilan reinforcement mengalami penurunan hal ini dikarenakan masih kurang terampilnya mahasiswa memotivasi anak untuk lebih kreatif dalam menghasilkan karya. Hal ini semakin didukung dengan hasil penelitian adanya penurunan dari nilai 75,5 pada siklus I naik menjadi 71 pada siklus II.

Keterampilan bertanya dasar merupakan teknik atau cara pendidik melibatkan anak agar berpartisipasi dalam menjawab pertanyaan pendidik selama pembelajaran. Adapun komponen keterampilan bertanya dasar adalah: 1) Pengungkapan pertanyaan secara jelas dan singkat, 2) Memberikan acuan, 3) Memusatkan perhatian, 4) Pemindahan giliran, 5) Penyebaran pertanyaan, 6) Pemberian waktu berfikir, 7) Pemberian tuntutan (Mukminan, 2013). Keterampilan bertanya dasar mengalami peningkatan hal ini dapat dilihat dari antusias anak sehingga fokus terhadap pertanyaan yang diungkapkan oleh anak. Hal ini semakin didukung dengan hasil penelitian adanya penurunan dari nilai 74 pada siklus I naik menjadi 76,5 pada siklus II.

Keterampilan bertanya lanjut meliputi 1) Pengubahan tuntutan tingkat kognitif, 2) Pengaturan urutan pertanyaan, 3) Penggunaan pertanyaan pelacak (Aisyah, 2007). Keterampilan bertanya lanjut mengalami penurunan hal ini dikarenakan masih kurang terampilnya mahasiswa untuk mengembangkan tingkat pemahaman kognitif anak selama proses pembelajaran berlangsung. Hal ini semakin didukung dengan hasil penelitian adanya penurunan dari nilai 77,5 pada siklus I naik menjadi 74,5 pada siklus II.

Berdasarkan dari hasil analisis data diperoleh data bahwa pada siklus I sebesar $74,8125 \%$ dan siklus II sebesar 76,9375\%. Hasil tersebut diperoleh berdasarkan hasil penilain observasi, oleh karena itu peneliti dan kolaborator merasa hasil yang didapat cukup dan memutuskan untuk menghentikan penelitian pada siklus II pertemuan ke Empat. Hasil tersebut dapat menunjukkan kesesuaian dengan hipotesis tindakan yaitu dengan presentase minimum sebesar $75 \%$ maka hipotesis diterima. Berdasarkan hipotesis tindakan yang menyatakan bahwa melalui penggunaan metode drill dapat meningkatkan kemampuan mengajar mahasiswa Semester V Prodi S1 Pendidikan Guru PAUD Fakultas Kependidikan dan Ilmu Pendidikan Universitas Bengkulu tahun ajaran 2019/2020. Prolehan presentase setiap mahasiswa pada setiap siklus berbeda-beda. Hal ini dapat dipengaruhi oleh faktor internal dan eksternal setiap mahasiswa. 


\section{SIMPULAN}

Keterampilan mengajar mahasiswa mengalami peningkatan setelah menerapkan metode drill. Hal ini terlihat dari hasil lembar penilain indikator keterampilan mengajar yang terdiri dari delapan aspek keterampilan mengajar diantaranya : 1) Keterampilan membuka pelajaran, 2) Keterampilan menutup pelajaran, 3) Keterampilan menjelaskan, 4) Keterampilan mengelola kelas, 5) Keterampilan variasi, 6) Keterampilan reinforcement, 7) Keterampilan bertanya dasar, dan 8) Keterampilan bertanya lanjut. Penerapan metode drill dapat meningkatkan keterampilan mengajar mahasiswa Semester V Prodi S1 Pendidikan Guru PAUD Fakultas Kependidikan dan Ilmu Pendidikan Universitas Bengkulu tahun ajaran 2019/2020. Peningkatan keterampilan mengajar mahasiswa mengalami peningkatan yang dikarenakan adanya proses pemahaman suatu materi secara mendalam mengenai kedelapan keterampilan mengajar, dilakukannya praktek secara langsung setiap mahasiswa yang dilakukan di rumah maupun di kampus, dan pengembangan keterampilan yang dilakukan secara berulang-ulang setiap aspek keterampilan mengajar.

\section{UCAPAN TERIMA KASIH}

Hamdan wa syukran lillah, Puji Syukur Kehadiran Allah SWT dengan Rahmat dan RahimNya telah melimpahkan penulis kekuatan, kesehatan, dan kemudahan dalam menyelesaikan paper ini. Terimakasih kepada Dekan Fakultas Kependidikan dan Ilmu Pendidikan Universitas Bengkulu yang telah memberikan pendanaan terhadap penelitian ini, serta kepada editor dan reviewer Jurnal Obsesi : Jurnal Pendidikan Anak Usia Dini yang telah memberikan informasih dan masukkan dalam penyempurnaan penulisan artikel ini.

\section{DAFTAR PUSTAKA}

Aisyah, S. (2007). Pembelajaran Terpadu. Universitas Indonesia.

Asrori, M., \& Rasyid, H. (2009). Penelitian Tindakan Kelas, Peningkatan Kompetensi profesional Guru. Multi Pressindo.

Astuningtias, K. I., \& Appulembang, O. D. (2017). Penerapan Metode Drill untuk Meningkatkan Hasil Belajar Kognitif Siswa Kelas IX Materi Statistika di SMP Kristen Rantepao. JOHME: Journal of Holistic Mathematics Education, 1(1), 53. https:// doi.org/10.19166/johme.v1i1.718

Djamarah, syaiful Bahri, dan A. Z. (2006). Strategi Belajar Mengajar. PT. Rineka Cipta.

Halimah, L. (2017). Keterampilan Mengajar sebagai Inspirasi untuk Menjadi Guru yang Excellent di Abad ke-21. PT. Refika Aditama.

Hidayat, H. S. (2016). Hubungan Minat Terhadap Profesi Guru dan Motivasi Berprestasi dengan Keterampilan Mengajar. Jurnal Pendidikan Dan Kebudayaan, 14(75), 1140. https:// doi.org/10.24832/jpnk.v14i75.375

Ismail, S. (2015). Membentuk Penguasaan Keterampilan Dasar Mengajar Mahasiswa Program Studi Pendidikan Matematika Peserta PPL-1 dalam Bimbingan Latihan Mengajar melalui Lesson Study. Konferensi Nasional Pendidikan Matematika Ke, 6, 1114.

Maiza, Z., \& Nurhafizah, N. (2019). Pengembangan Keprofesian Berkelanjutan dalam Meningkatkan Profesionalisme Guru Pendidikan Anak Usia Dini. Jurnal Obsesi : Jurnal Pendidikan Anak Usia Dini, 3(2), 356. https:/ / doi.org/10.31004/obsesi.v3i2.196

Mansur, N. (2017). Penerapan Keterampilan Mengajar Dalam Upaya Pencapaian Hasil Belajar Mahasiswa. Lantanida Journal, 4(2), 118. https:/ / doi.org/10.22373/lj.v4i2.1884

Marwiyati, S., \& Istiningsih. (2021). Pembelajaran Saintifik pada Anak Usia Dini dalam Pengembangan Kreativitas di Taman Kanak-Kanak. Jurnal Obsesi: Jurnal Pendidikan Anak Usia Dini, 5(1), 135-149. https://doi.org/10.31004/obsesi.v5i1.508

Mukminan. (2013). Modul Pelatihan Pengembangan Ketrampilan Dasar Teknik Instruksional (PEKERTI). Universitas Negeri Yogyakarta Pusat Pengembangan Kurikulum.

Nikmarijal \& Ifdil. (2014). Jurnal konseling dan pendidikan. Jurnal Konseling Dan Pendidikan, 
DOI: 10.31004/obsesi.v5i1.506

2(2), 55-61.

Nuridin, N., Jupriyanto, J., \& Frastika, R. A. (2019). Pengaruh Keterampilan Mengajar Guru Terhadap Aktivitas Belajar Siswa SD Negeri 04 Loning. Jurnal Ilmiah Pendidikan Dasar, 6(1), 45. https://doi.org/10.30659/pendas.6.1.45-51

Nurlaili, N. (2018). Analisis Keterampilan Dasar Mengajar Guru Dalam Perspektif Guru Pamong Pada Mahasiswa Prodi PGMI Fakultas Ilmu Tarbiyah dan Keguruan UIN Raden Fatah Palembang. JIP: Jurnal Ilmiah PGMI, 4(1), 28-40. https://doi.org/10.19109/jip.v4i1.2270

Oliver, J. (2019). Summary for Policymakers. In Intergovernmental Panel on Climate Change (Ed.), Climate Change 2013 - The Physical Science Basis (Vol. 1, Issue, pp. 1-30). Cambridge University Press. https://doi.org/10.1017/CBO9781107415324.004

Rahmadani, P., Kaswari, \& Rosnita. (2015). Penggunaan Metode Latihan (Drill) untuk Meningkatkan Kemampuan Menulis Puisi Siswa Kelas III C. Jurnal Pendidikan Dan Pembelajaran Khatulistiwa, 4(9).

Roestiyah. (2008). Strategi Belajar Menajar. PT. Rineka Cipta.

Safitri, E., \& Sontani, U. T. (2016). Keterampilan Mengajar Guru Dan Motivasi Belajar Siswa Sebagai Determinan Terhadap Hasil Belajar. Jurnal Pendidikan Manajemen Perkantoran, 1(1), 144. https:// doi.org/10.17509/jpm.v1i1.3258

Salma, Y., \& Fatmawati. (2019). Metode drill dalam meningkatkan keterampilan membuat tas makrame untuk anak tunarungu di slb bina bangsa. Jurnal Ilmiah Tumbuh Kembang Anak Usia Dini, 4(3), 27-34.

Saragih, A. H. (2008). Kompetensi Minimal Seorang Guru Dalam Mengajar. Jurnal Tabularasa, 5(1), 23-34.

Taja, N., Inten, D. N., \& Hakim, A. (2019). Upaya Meningkatkan Keterampilan Mengajar Baca Tulis Al-Qur’an bagi Guru. Jurnal Obsesi : Jurnal Pendidikan Anak Usia Dini, 3(1), 68. https:// doi.org/10.31004/obsesi.v3i1.135

Wahyu, Syambasril, D. (2017). Penerapan Metode Drill untuk Meningkatkan Keterampilan Menyimak Siswa Kelas VII SMPN I Bunut Hulu. Jurnal Pendidikan Dan Pembelajaran Khatulistiwa, 6(1), 1-11.

Wahyulestari, M. R. D. (2018). Keterampilan Dasar Menagajar Di Sekolah Dasar. Prosiding Seminar Nasional Penelitian, Pendidikan Dan Penerapan MIPA, 199-210.

Wahyuni, L. (2015). Hubungan Keterampilan Mengajar Guru dengan Minat Belajar Siswa. Jurnal Pendidikan Guru Sekolah Dasar, 4(11). 